Global Journal of Arts, Humanities and Social Sciences

Vol.10, No.1, pp.21-38, 2022

Print ISSN: 2052-6350(Print)

Online ISSN: 2052-6369(Online)

\title{
THE INFLUENCE OF RELIGION AND MARRIAGE ON WOMEN'S LEADERSHIP IN ASHANTI REGION OF GHANA
}

\author{
Simon Kyei, (Ph.D.) \\ University of Education, Winneba Ghana
}

\begin{abstract}
Citation: Simon Kyei (2022) The influence of religion and marriage on women's leadership in Ashanti region of Ghana, Global Journal of Arts, Humanities and Social Sciences, Vol.10, No.1, pp.21-38
\end{abstract}

\begin{abstract}
This paper focuses on how religion and marriage cultures in Ghana influence women to be ruled by men. As a descriptive research, it used qualitative research approach and adopted descriptive statistics as it used basic tables and graphs to explain the findings. The major finding was that marriage and religion have potential to prevent women from become leaders as women are likely to obey the marriage and religious principles that group women and men into subordinates and leaders respectively. The conclusion made was that as religion and marriage cultures coerce women to accept that men are to lead them in all spheres of life, the radical feminists who see men as enemies and call for emancipation as means to address the situation are likely to fail in their approach. On the other hand, social and liberal feminists who call for education as means to address the man and women status disparities problem are likely to be comfortable in marriage and religion and succeed in becoming leaders in the society as well
\end{abstract}

KEYWORDS: gender othering, marriage, religion, feminism, leadership

\section{INTRODUCTION}

It is said that what staggers behind all dimensions of gender sensitive policies is governance. As a result, there has been a tremendous increase in awareness of the political importance of gendersensitive economic development and policy reform which, has influenced policy and decision makers to give considerable attention to the role women play in politics. Moreover, many development partners and international investors in the $21^{\text {st }}$ century have realized that good governance promotes transparency and fosters an efficient environment for achieving policy objectives (Oman \& Arndt, 2006). Good governance cannot be perfected with the involvement of women. The issue associated with women joining the main stream of leadership for governance is whether or not the society accept women as competent enough to lead. This paper equates the religious influence to the voice of the religious leaders and marriage influence to the voice of the husbands and wives.

The concept of women's political empowerment is embedded in protection of women's rights and the efforts to include women in political decision taking. These are rooted in human rights treaties such as 1995 Beijing Declaration and Platform for Action which made a concerted effort to strengthen women's participation in decision-making; the Millennium Development Goals which also intended to promote gender equality by focusing on women's role in governance. Others

@ECRTD-UK: https://www.eajournals.org/

https://doi.org/10.37745/gjahss.2013 
include the 1979 Convention on the Elimination of All Forms of Discrimination Against Women (CEDAW) which provides a comprehensive framework to guide all rights-based action for gender equality; the 1993 Declaration on the Elimination of Violence against Women (DEVAW) - a human rights instrument that exclusively and explicitly addresses the issue of violence against women, affirms that the phenomenon violates, impairs or nullifies women's human rights and their exercise of fundamental freedoms. DEVAW declaration provides a definition of gender-based abuse to mean any act of gender-based violence that results in, or is likely to result in, physical, sexual or psychological harm or suffering to women, including threats of such acts, coercion or arbitrary deprivation of liberty (Chung, et al 2013).

Agencies such as UNDP, USAID, the World Bank and, UN Women which seeks to promote women's leadership and political participation at all levels for gender equality and the empowerment, have based on the above frameworks to develop indicators to measure the quality of women's development in governance (Scott and Wilde, 2006). Studies have shown that the most common means to empower women politically initiated by agencies and governments are efforts to see women in decision-making positions in local government/parliament or in local civil services/ministries and governmental committees; their right protections; and involvement in electoral systems (Corner and Repucci, 2009). Scott and Wilde (2006) stated that the common indicators normally used to measure women representation in governance include women's influence on high-level decision making and treatment of women within the justice system. For the electoral systems and process, the agencies and governments track progressions of women's activities and initiatives made through political and civic engagement. In the area of human right and justice, women's awareness of their rights, their trust in the justice system, and their access to it are the common indicators.

However, as there are enough data to show that some gains have been recorded in terms of legal and institutional progress towards more women in decision making, it has been said that political power, right from homes to the national and international levels, still resides in the hands of men (Chung, et al, 2013). UN Women (2014) has cited pervasive structural factors such as cultural attitudes based on patriarchal models, gender stereotypes and traditional roles of men and women, deficiencies in women's political and economic empowerment - poverty, low education among girls, as well as gender violence as hindrances or limitations in ensuring of women's political rights. UN Women (2014) has however noted that it is possible to change those same structural factors that exclude women from political activities "through quantitative and qualitative increase in women's participation and leadership in areas of political decision-making. Their involvement in decision-making is a precondition for the public agenda to incorporate new dimensions in public policies that contribute to put an end to the vicious circle of discrimination and gender inequality".

In Ghana, it seems that the use of decentralization to involve women in politics has also failed. In the year 2020 elections in Ghana, out of 275 members of parliament, only 40 women were elected as parliamentarians representing $28.5 \%$. In the 2016 elections, only 36 (12.8\%) out of 275 were females. Talking political decentralization processes, Capacity.org -Issue 40 (2010) editorial comment stressed that the problem with decentralization in Africa is that usually little power is

@ECRTD-UK: https://www.eajournals.org/ https://doi.org/10.37745/gjahss.2013 
devolved from central government and few financial resources are transferred to the local government. Even this, the woman finds it difficult to be involved since the local government are highly politicized, contested and has become a conflict-prone site. As many societies are patriarchal in nature, men continue to rule as chiefs, kings, land owners, and leaders of families.

Women inability to make meaningful contribution in decision making, at all levels - home, district and the national levels, has the potential to make it difficult for women to rule their lives. Literature has shown that women suffer from number of abuses due to the fact that they are unable to rule their world. They suffer enough from domestic violence simply because they do not make much decision at home. Thus, women normally suffer from cultural norm brutalities because their say at home and in the society is limited. Since they lack fair representation at the national levels, they sometimes suffer from jobs and occupational unfairness. As minority group in national legislation, women face the sharp edges of the law which always suppress them into subordinations. For instance, UN women (2014) has identified that when women have strong political voice and influence, they would influence political and public decisions to have a gender and ethnic perspective, which in effect, leads to a better, more inclusive governance that recognizes women's diversity. Thus, UN women (2014) was with the view that ensuring political empowerment of women lead to the promotion of their economic and social empowerment, equal access to opportunities and resources, more safety, greater prevention and efficiency of the justice system against gender violence. For example, Rwanda (as a country) in her 2003 constitution, gave quotas to women in decision-making and, it appears the move has positive effect on women's political empowerment. The high representation of women in parliament in the country is a direct indication of good governance. Additionally, the country established a stronger focus on advocacy, education, and gender-sensitive laws to fight against gender violence and ensuring of other political empowerment dimension (Bugingo and Interayamahanga, 2010).

The gap that still exists between the male and female in terms of political power is established in patriarchal nature of Ghanaian set ups despite global and regional treaties which the country has been implementing over the years to empower women politically. Comparatively, women are not empowered as expected. The problem is therefore not lack of laws and interventions to empower women politically but in most cases, tagging women with inferiority complex such that men become the icons in political leadership. This paper therefore seeks to identify how religion and marriage prevent rural women in the Ashanti Region of Ghana from decision making as marriage and religion create othering in decision making. The study answers the question of how religion and marriage influence rural at home and in national politics.

\section{REVIEW OF RELATED LITERATURE}

According to Berik, et al (2012) women face many barriers than men in participating in the deliberative bodies and entities that make rules and policies affecting redistribution of resources and restricting of economic opportunities. As men dominate the political arena and formulate the rules of the political game, they define the standards for evaluation. Thus, three interlinked 
pathways have been identified to promote equitable distribution of political opportunities. These are Right, Resources and Voice (Berik et al, 2012). The World Bank has defined right in terms of political, social, economic and legal rules as that constrain women's choices such as rules that prevent women to own land or to become kings. Data available indicate that the population of women is higher than men but they (women) are underrepresented in political leadership positions throughout the world. In the year 2000 for example, women comprised only $13.8 \%$ of all parliament members in the world, up from 9\% in 1987 (Beaman, et al, 2006). In the year 2019, the IPU reported that the number of women in parliament has increased to $24 \%$. According to Inglehart et al (2003) between 1995 to the year 2000, political representation had the least gap narrowed whilst other areas such as economic opportunities, education and legal rights, did appreciate some gains. Such constraints inhibit women's command over productive resources such as education, information and financial resources which limit access to paid work and wages (Berik, et al, 2012). It can then be concluded that in a situation whereby the distribution of political power is the root cause of gender inequality such as control of resource, violence against women and income differences and, factors that imitate against women to assume leadership position needs critical attention. As Tilly (1998) put it, such factors as culture and religion affirm the durability of the existing inequality.

Apart from culture, there are other factors that account for unfair distribution of political opportunities and resources among men and women. There are generic interactive processes that create gender inequalities. These interactive processes, according to Risman (2004) include othering and subordinate. This paper uses theories such as deficit thinking theory, critical theory and feminism as a framework to establish how marriage and religion interactions fuel rural women political leadership inequality as others, such as husbands and religious leaders interplay in such societal institutions.

The simplest way to relegate an Africa woman to the background in all spheres of life is through institution of marriage and religion. In these two institutions, there is always respect for others. From literature, Othering simply means actions by which people are mentally classified into superior and inferior groups. Jensen (2011:65) defines othering, as:

discursive processes by which powerful groups, who may or may not make up a numerical majority, define subordinate groups into existence in a reductionist way which ascribe problematic and/or inferior characteristics to these subordinate groups. Such discursive processes affirm the legitimacy and superiority of the powerful and condition identity formation among the subordinate.

It has been noted that as othering creates identity among people, it has three dimensions. First, it makes the subordinates aware of who holds power - through interactions and socialisation processes. Thus, some others are produced as subordinates. Second, some others are constructed to be pathologically and morally inferior. Third, knowledge and technology belongs to 'the powerful empirical self, and not the colonial other' (Jensen, 2011: 65). Acceding to Seidman, (2013) and Jensen, (2009) the world is not organised to benefit women because they are seen as

@ECRTD-UK: https://www.eajournals.org/ https://doi.org/10.37745/gjahss.2013 
people with limited knowledge in all things that matter most and they must adapt to the rules. Thus, husbands are likely to control wives in power play in marriage. Also, women are seen as morally and pathologically unfit to be allowed to lead. Thus, women in the church are likely to be relegated to the background in church leadership. It must therefore be noted that the moment people begin to cite others as people with repository of knowledge, these people have preferences in who should lead politically and socially. Gender othering is used to mean cognitive bias against women's ability to function well as male counterpart in all spheres of live. This study limits gender othering to how religion and marriage out group women in decision making.

\section{Cognitive Theory}

Reskin, (2000) explained that Social Cognitive Theory holds it that people automatically categorize others into 'in groups and out groups'. As a results, it creates identity among groups. The visibility and cultural importance of sex and race grouping and their role as core bases of stratification make them almost automatic bases of categorization. Thus, generally, having categorized others or people into the same category turns to automatically push them to feel, think, and behave alike. It is well noted that categorization is accompanied by stereotyping, attribution bias, and evaluation bias. These, in turn, introduce sex, race, and ethnic biases into people's perceptions, interpretations, recollections, and evaluations of others. These biases are cognitive rather than motivational (Reskin, 2000:320-27; Krieger 1995: 1188).

\section{Deficit Thinking Theory}

Deficit thinking, according to Valencia (2010) is an endogenous theory suggesting that some group of people (such as women) lack power due to deficiencies or deficits they themselves have. Valencia (1997) was with the view that genetics, culture, class and familial socialization have all been postulated as the sources of the alleged deficits. Women are religiously trained to have in them leadership deficiency as men are always seen as genetically fit from the beginning of creation. Deficit thinking theory has been criticized on the ground that the theory is unreasonably simplistic, grounded in classism and racism (Swadener and Lubeck 1995). However, Valencia (1997) held the view that since deficit thinking displays great diversity or is so protean, I hold a view that it does not cease to be relevant in determining how religion and marriage can contribute to the deficiencies in women to become leaders in the society.

Operationally, this paper adopted the deficit thinking theory as a focal theory. Deficit thinking theory as applied to social class classification, refers to the notion that people in positions of power such as husbands and religious leaders automatically make assumption that women as a social class are more prone to social problems and are less powerful such as earning low income, attaining low education or not at all; are more vulnerable than others, and inferior to others, and therefore cannot become leaders in the society (Valencia, 1997; Ryan, 1971). Drawing logical conclusion from what this paper makes out of the view of deficit thinking theory, it could be said that religious leaders and husbands see women as poor and weak; vulnerable, inferior to men; and therefore need to be led. The rural women are considered to be the worst of women. Theorizing the nature of rural women's status, the study employs feminism as bases. 
Global Journal of Arts, Humanities and Social Sciences

Vol.10, No.1, pp.21-38, 2022

Print ISSN: 2052-6350(Print)

Online ISSN: 2052-6369(Online)

\section{Feminism}

The status of women and the approach to unearthing women potentials has been opined by various category of feminists. Feminism therefore forms a theoretical framework in explaining the status of the woman in the rural society. Feminist conflict theorists such as Bruegel (1979) argue that women have traditionally been oppressed so that men can benefit from positions of power, wealth, and status. These theorists would argue that the conflict over limited natural resources is what led men to relegate women to domesticity. As it had already been said this statement is interpreted to mean that men cannot be trusted to give power to women because this gift would conflict with their inherent nature. The position of these radical feminists is that men are simply enemies. To them, women emancipation is the key concept and that the better approach to free women is through the separation of women from male domination. Willis (2007) stated that emancipation approach helps to create awareness for the oppressed group to develop ways of overcoming all forms of oppressions.

Liberal feminists argued that differences that exist between men and women are as a result of socialisation and 'sex-role conditionings' and the cultural expectations of one's society (Risman, 2004; Smeler, 1998). To them, Girls cannot develop their full potentials due to the preferential treatment parents and the society give to the boy-child right from birth. To these liberalists, women are oppressed in the society to the extent that they become subordinates to men. Liberal feminists prefer the use of the advocacy, support, and education to fight for equal rights as the best approach.

Socialist feminists are with the view that the disparities between women and men do exist due to the fact that capitalism and patriarchal societies give men power over women (Pilcher and Whelehan, 2004). Therefore, the emergence of industrialisation and the conflict over limited resources resulted in the women losing certain legal right and were excluded from certain spheres of the paid work. They were relegated to the background and settled on motherhood and household work. They then limited themselves to have access to few areas of paid work (Bruegel, 1979). Thus, women serve the needs of capitalism because they form the cheap source of labour. However, under the same condition, men gained certain political, economic, social and legal rights to dominate over all aspect. Thus, socialist feminists prefer the promotion of girl-child education to fight for equity in resource control. Cuddy, et al, (2007) were with the view that people in the up class are not only respected but are also competent in all issues that matter most. Ridgeway (2014:4) concluded that people with higher status "have fairly won their better jobs and higher incomes on the basis of their own superior merit. It thus provides an especially powerful form of legitimation in an ostensibly meritocratic society". This group prefer women economic empowerment to other means of solving the problem.

Black feminists are with the view that the black women suffer double disadvantage- patriarchy and racism (Collins, 2000). In line with my argument and the clue I take from Livesey and Lawson (2008) that the category of women who suffer most under the societal class creation are those whose work put them under no supervisory role - those women are mostly located in the rural areas and those dwell in city slums, face third hurdle. The third hurdle that the black women in the rural communities face is their ability and capability to position themselves well to benefit fully from the opportunities created by democracy for women leadership. There is always a gap between

@ECRTD-UK: https://www.eajournals.org/

https://doi.org/10.37745/gjahss.2013 
Global Journal of Arts, Humanities and Social Sciences

Vol.10, No.1, pp.21-38, 2022

Print ISSN: 2052-6350(Print)

Online ISSN: 2052-6369(Online)

opportunities created for all women to be leaders and the extent to which the rural women can position themselves to benefit from the opportunity created.

\section{Religion, marriage and women political status}

Every religion in the world contains cultural mores and norms which regulate the conducts of men and women. However, data available show that Muslims and Buddhists seem to have less egalitarian gender role attitudes than the Christians even if some factors are controlled (Inglehart and Norris, 2003b). According to Predelli (2004) different gender roles do exist within Islam and that public discourse seems to equate Islam to gender inequality. Despite differences in religions across the world, similar normative claims about men's and women's roles are present across all denominations. In any case, as evident in many writers' accounts, women are always in the disadvantageous positions as far as status in who lead is concern (Predelli, 2004; Inglehart and Norris, 2003b). Wadud (1999) stated that Muslim feminists however, are in strong demand that men should share the domestic work with women if not equally, at least at higher proportions to give Muslim women the chance to be involved in the public roles and leadership positions. The difficulty which these Muslim Feminists face in fighting for gender equality is exactly the 'story of Shahbanu, an India woman who joined other Muslims in India to fight against a Supreme Court decision in her favour against her divorced husband. The story, as told by Rouhana (2003) states:

In 1978, Shahbanu, a 70-year-old Muslim woman from India, filed an appeal to the judicial magistrate under Section 125 of the Criminal Code, demanding alimony from her wealthy husband, Mohammed Ahmed Khan, who threw her out of her home after 43 years of marriage. While the application was pending, Shahbanu's husband divorced her, paid her Rs3, 000 as mehr (dowry), and claimed she could no longer demand anything from him. The magistrate, however, ordered him to pay Rs 25 per month, and Shahbanu got the sum raised to Rs179.20 in the High Court. Shahbanu's husband appealed to the Supreme Court, arguing that under Muslim Personal Law, he had no responsibility to pay maintenance to his divorced wife, and therefore Section 125 did not apply to him. In April 1985, the Supreme Court ruled in favour of Shahbanu. The Supreme Court's ruling created a furor among the Muslim population. ...Muslim leaders denounced the decision as the beginning of government attempts to interfere in the personal issues of the Muslim minority. These leaders declared that "Islam is in danger," and protests erupted throughout the country, with demonstrators demanding that Section 125 not apply to Muslim women. Shahbanu herself endorsed this demand, condemning the court's judgment in a public letter addressed to all Muslims, despite the fact that it supported her claims. The Muslim Personal Law Board intervened in the case on behalf of Shahbanu's husband and, unsuccessful in the Supreme Court, carried the battle to the Parliament. A Muslim Member of Parliament introduced a bill entitled the Muslim Women (Protection of Rights in Divorce) Act, which was passed in May 1986. According to this new act

This is a clear example of how religion and marriage combined can render women subjects to men. The question this study concerns itself with is, are such situations as in shahbanu case, the truth in the theories of deficit thinking and cognitive as argued out by various feminists theorists exist in the study area? The literature reviewed suggests that as others are seen as inferior and therefore cannot leader, others are seen as the repository of knowledge skills and all qualities in leadership to lead. What is not captured is how beyond thinking the behaviour of others relegate others to the

@ECRTD-UK: https://www.eajournals.org/ https://doi.org/10.37745/gjahss.2013 
background such that others could lead others. The niche to be filled is how religious and marriage as institutions behaviour towards women to relegate them into out-group of leadership.

\section{THE STUDY METHODOLOGY}

This study used qualitative research approach and descriptive statistics research design. The qualitative data derived from the respondents were expressed and analysed in words (Twumasi, 2001; Brown, 1996). However, there were descriptive statistics where data derived from the respondents concerning the political status of the women in the study area and the measurement and analysis of causal relationships between these variables were also presented in basic tables, diagrams and percentages.

The use of qualitative inquiry in this study makes the study holistic because the whole phenomenon under study is understood as a complex system that is more than the sum of its parts; naturalistic because it studies real world situations as they unfold; and, it is empathetic neutrality with the researcher passionately seeking understanding of the word, rather than either ephemeral objectivity or a subjectivity that undermines credibility (Patton, 1990). The study also applied Jacob's (1988) qualitative domains such as:

- The ecological psychology domain, which investigated the relationships between people and their environment in order to identify ways of shaping their lives.

- The Holistic ethnography domain concentrating on effects culture has on people.

- The symbolic interaction domain which is interested in how people make sense of their world and assign meaning in interaction with others.

The population for this study comprises rural women in three Districts in Ashanti Region of Ghana. These districts were Amansie West District (Manso Nkwanta), Bosomtwe District (Kuntanase), and Asokore Mampong. It was also include the key informant - Ashanti Region Desk Officer for Ministry of Gender. The sampling technique adopted in this research include probability and nonprobability sampling. As Twumasi (2001) noted, the key considerations in the selection of fair representatives in a given population in a social science research include the use of these two sampling techniques. The probability sampling technique used to select 50 women each, from each district as respondents for this study is simple random sampling which gave every group member an equal chance to be selected through lottery method (Twumasi, 2001; Sarantakos, 2012). The sample frame was the list of married women in the various local churches and mosque in the capital cities of the selected districts. Amansie West was selected to represent all the remote districts in the region, low education levels and different dynamisms in culture; Bosomtwe Districts, to represent a district with different kinds of economic activities; and Asokore Manpong, where women living in the Asokore Mampong Zongo and slums communities were captured to represent rural within the urban (GSS, 2014). This gives a fair representation in terms of different conditions under which political leadership dynamisms operate as well as different economic and social conditions operate to influence decision in homes. Non-probabilistic method was also used in the selection of institutional stakeholder as a key informant for the relevant data.

@ECRTD-UK: https://www.eajournals.org/ https://doi.org/10.37745/gjahss.2013 
A total of 150 married women, aged between 24 to 60 years, were selected for the study. This means that all the 150 women respondents from all the three Districts were interviewed using interview schedule. From each district, 10 Muslim women and 40 Christian women were selected. The large number (150) was necessary because each district as well as individual has different situation to share. Three groups made up of 10 members (men) from each district were purposively selected (also from church and mosque lists) to involve in focus group discussion. Only men from Asokore Mampong were Muslim. Karma (2018) held the view that the choice of a study sample size is at the discretion of the researcher. Hence, discretion was used rather than saturation.

\section{Influences of marriage and religion in women leadership}

One major issue that comes up anytime gender inequality is to be addressed is women and decision making. The background literature suggested that decision making in the local and national levels in many parts of the world are mostly done by men. The adverse effect among many, is that women find themselves in disadvantageous position as such decision normally favour the 'makers'. Thus, the respondents of this study were asked if they take part in the decision making (both at home and at the district level politics) and how their religions and marriages influence their decision making.

\section{Women and Decision Making at Homes}

Charity, they say, begins at home. Leadership always starts from homes. This paper wanted to establish how rural women fair in decision making at home as it looks at the circumstances under which wives in the study areas' husbands allow them to lead in decision making.

Table 1 below shows the number of respondents who do have the opportunity to either lead in decision making at home or collectively take decisions with the husband, or it is the husband who take decision along.

Table 1. Women Involvement in Decisions Making at Home

\begin{tabular}{|c|c|c|}
\hline \multirow{2}{*}{ Who makes Decision in the house } & \multicolumn{2}{|c|}{ Frequency } \\
\cline { 2 - 3 } & Number & \% \\
\hline Husbands & 116 & $\mathbf{7 7}$ \\
\hline Self & 21 & $\mathbf{1 4}$ \\
\hline Collective & 13 & $\mathbf{9}$ \\
\hline Total & $\mathbf{1 5 0}$ & $\mathbf{1 0 0}$ \\
\hline
\end{tabular}

Sources: Field survey, 2021.

Table 1 shows that $77 \%$ of the respondents said it is the husbands who take decisions at home. A figure close to $9 \%$ said they do share their views in the decision making at home. And, $14 \%$ of the respondents do make decisions at home themselves without husbands' interference. The $77 \%$ of 
Vol.10, No.1, pp.21-38, 2022

Print ISSN: 2052-6350(Print)

Online ISSN: 2052-6369(Online)

the respondents whose husbands have final say in the house said they can only offer advice. This means that 116 out of 150 married women do not involve themselves decision making at home. These decision affect them but they are to obey and to make any inputs. Some of the husband talk to in focus group discuss with the view that their wives advice in most cases, lead them to problems.

Consulting a wife to decide on what to do is like doing without thinking or giving a leadership to a shallow minded leader, the end results is ditch. - A husband from Asokore Mampong

The category of women, or type of women who do take part in the decision making (collectively) in these homes is important to find out. What is the relationship between the education, and income level of these women and their ability to share thoughts with the husbands? It was found out that there is direct link between the women's income, their levels of education and their ability to have their voices heard in the decision taking at home. In the figure 1 below, the number of women who could contribute collectively to the decision making was investigated.

Figure 1. Women Social Status and their Contribution to Decision Making at Home

\section{Source: Field Survey, 2021}

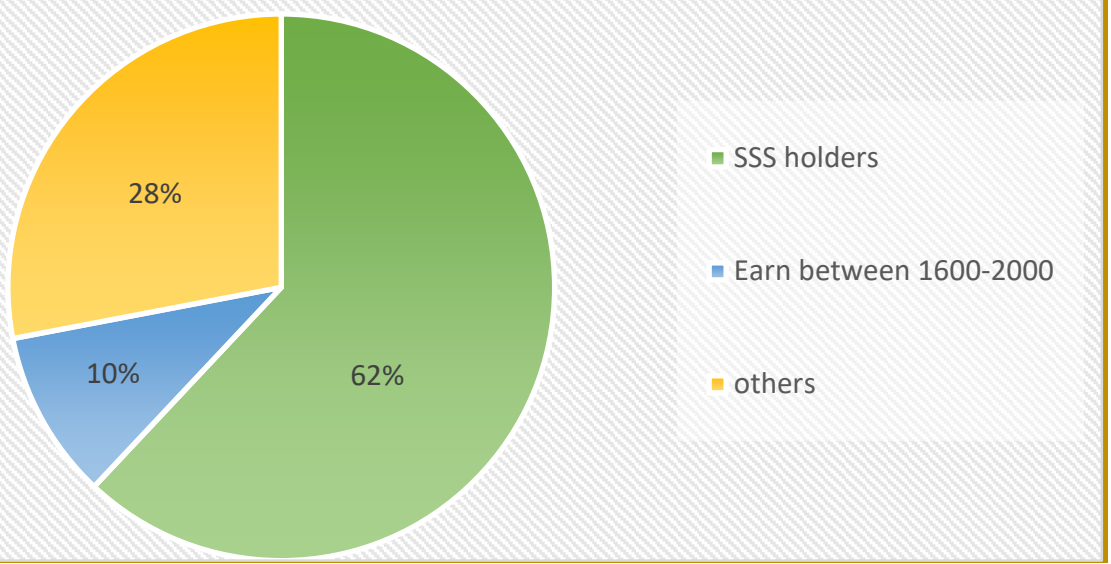

From the chart above, about $72 \%$ of the women who responded to the study were either have senior high school education or earn between thousand six hundred Ghana cedis and two thousand cedis a month. That is, $62 \%$ of them have senior high school certificates, $10 \%$ of them earn between thousand six hundred to two thousand cedis per month. The rest, about $28 \%$ of them neither have secondary school education nor earn above six hundred Ghana cedis per month.

Thus, women respondents who have good financial status and secondary education do contribute to decision making at home. This confirms the claim made by Cuddy, et al, (2007) that people in the up class are not only respected but are also competent in all issues that matter most. Ridgeway (2014:4) concluded that people with higher status "have fairly won their better jobs and higher incomes on the basis of their own superior merit. It thus provides an especially powerful form of 
Global Journal of Arts, Humanities and Social Sciences

Vol.10, No.1, pp.21-38, 2022

Print ISSN: 2052-6350(Print)

Online ISSN: 2052-6369(Online)

legitimation in an ostensibly meritocratic society". What it means is that women will be able to win respect from men, especially their husbands and from the society on merit. If women are allowed to participate in decision making because they earn more income, then they earn their respect based on belief that they have achieved the expected status. Hence, the cognitive bias is at play.

From the husbands' perspective on women sharing in decision making, there were two schools of thought. As one group believe that wives' contribution to decision making is productive, others see it as counterproductive. Here are excerpts from the two:

Yes, I agree, but how can a wife take a quality decision to push the entire family forward and moving? They, in most cases, act in a bad faith and out of emotions, greed and fear. I don't trust them no matter their education and wealth - A husband from Manso Nkwanta.

Allowing a woman to take a decision for the family is like leaving a car to unqualified driver to drive, the end result is ditch-A husband from Bosomtwe.

Women have very good hindsight and foresights. Involving them if decision making in marriage brings peace and good vision - A husband and a church leader at Bosomtwe

My wife and I never argue because I normally take the initiative and she polishes it up. I do get it done well when I involve her-A man at Asokore Mampong

Women were also interviewed on principles that guide them in marriage. They were tasked to give information on their views on traditions and religious principles that direct and guide them in relation to their husbands. Most of the respondents $-89 \%$ stated that they adhere to teachings of Bible and Quran for their everyday lives. Some of them have these to say:

The bible entreats us to be submissive to our husband. Ephesian 5 verse 23 said so. No matter how much I try in live, my husband must control all my decisions - A Christian woman at Asokore Mampong

Traditionally, men can marry two, I understand. My husband is the leader of the house. He decides the number of children to have with me. He is my leader and consultant - A Christian woman at Bosomtwe.

Islam does not allow wives to be rude to their husband. In fact, Quran 4:34, even gives the husband the power to discipline the disobedient wives by first admonish them. Second, decide not to share the bed with them and last, give a slight beat. We are for them, whom am I to go contrary to my husband's instructions? - A Muslim woman at Asokore Mampong

@ECRTD-UK: https://www.eajournals.org/

https://doi.org/10.37745/gjahss.2013 
Vol.10, No.1, pp.21-38, 2022

Print ISSN: 2052-6350(Print)

Online ISSN: 2052-6369(Online)

About $11 \%$ of the respondents stated that religion does not prevent women to lead men at home or in a country. About $98 \%$ of this category of respondents were Christians. As men supposed to be providers does not mean they are automatic leaders. They contended that power play in marriages is based on who feed who, and who contributes to what. They think they are modern women and cannot act strictly to bible principles. Apart from one Muslim woman who was in Asokore Mampong, all other women with this view were educated. Factors that limit women's contribution to decision making is not only limited to education and income levels but also the religious and husband influence.

Table 2.

Whom Women Prefer to Consult Most for Political Decisions Making

\begin{tabular}{|c|c|c|}
\hline \multirow{2}{*}{ Respondents' Advisors } & \multicolumn{2}{|c|}{ Frequency } \\
\cline { 2 - 3 } & Number & $\mathbf{6 1}$ \\
\hline Religious leaders & 91 & $\mathbf{2 5}$ \\
\hline Husbands & 38 & $\mathbf{1 4}$ \\
\hline Others & 21 & $\mathbf{1 0 0}$ \\
\hline Total & 150 & \\
\hline
\end{tabular}

Source: Field survey, 2021

Table 2 above shows whom the respondents would consult for final direction should they decide to vie for any political position. The Table shows that close to $61 \%$ of the respondents would like to take whatever the religious leaders (Pastors and Mallams) would say about their intension to contest in an election. Other 39\% would either listen to the husbands and other relatives or consider their own capabilities. Thus, majority of the women who responded to the study are likely to either be prevented from taking a leadership role or be urged on, depending on what the husbands and church leaders ask them to do or the interest of the husbands or church leaders. Interestingly, Muslim women and Christian women have different level of influence from their husbands and religious leaders. Figure 2 shows how religion and marriage can influence Christian and Muslim women differently. 
Vol.10, No.1, pp.21-38, 2022

Print ISSN: 2052-6350(Print)

Online ISSN: 2052-6369(Online)

Figure 2. Marriage and Religion Influence on Women's Political Decision Making

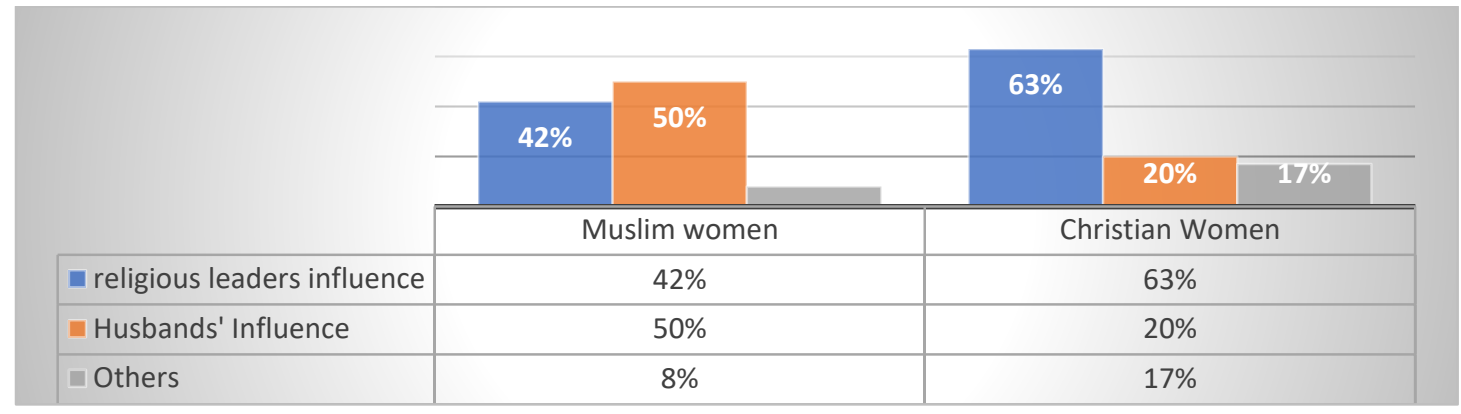

Source: Field survey, 2021

From the figure 2, only few of each group will listen to other relatives or look at their own competencies as against advice received. All others said they will discontinue or get the urge to vie for the position if the husband, pastors and Malams ask them to do so. A vast majority of Christian women who responded to the study (63\%) prefer to listen to the pastors' final advice on whether or not they should take leadership position in the church or in politics whilst Muslim women respondents (50\%) will listen to their husbands. The influence of religious leaders on women's decisions is very crucial especially among the modern Christians. An appreciable number of Muslim women (48\%) will listen to their religious leaders before such decision is taken. The study shows that majority of the women who responded to the study will choose religion ahead of their other rights. This current study confirms the report given by Rouhana (2003) which suggests that an Indian woman, Shahbanu fought against a court decision to grant her wish after she realized that the court decision was against her religion. Thus, it can be deduced that both religious culture and spirituality contribute to gender inequality as it turns to influence women decision making negatively.

When the husbands (men) were engaged in whether or not they would encourage their wives to take leadership positions in politics, the response was unanimous and emphatic that, only if their wives were to earn something huge, they would allow.

The respondents' decision on whether or not a woman should be selected as a leader show that women themselves agree that men are more competent than they (women) do. Their responses do confirm what Jensen, (2009), and Seidman, (2013) had said that women are pathologically and morally seen as inferior but, knowledge and skills belong to men. This is evident in the answers they gave to a question, "Who do you prefer, a woman or man as your MP/DCE, and why?" Figure 3 gives the statistics on the responses given. 
Figure 3. Respondents' Reasons for Choice of Political Leaders

a. Preferences based on competency and other reasons

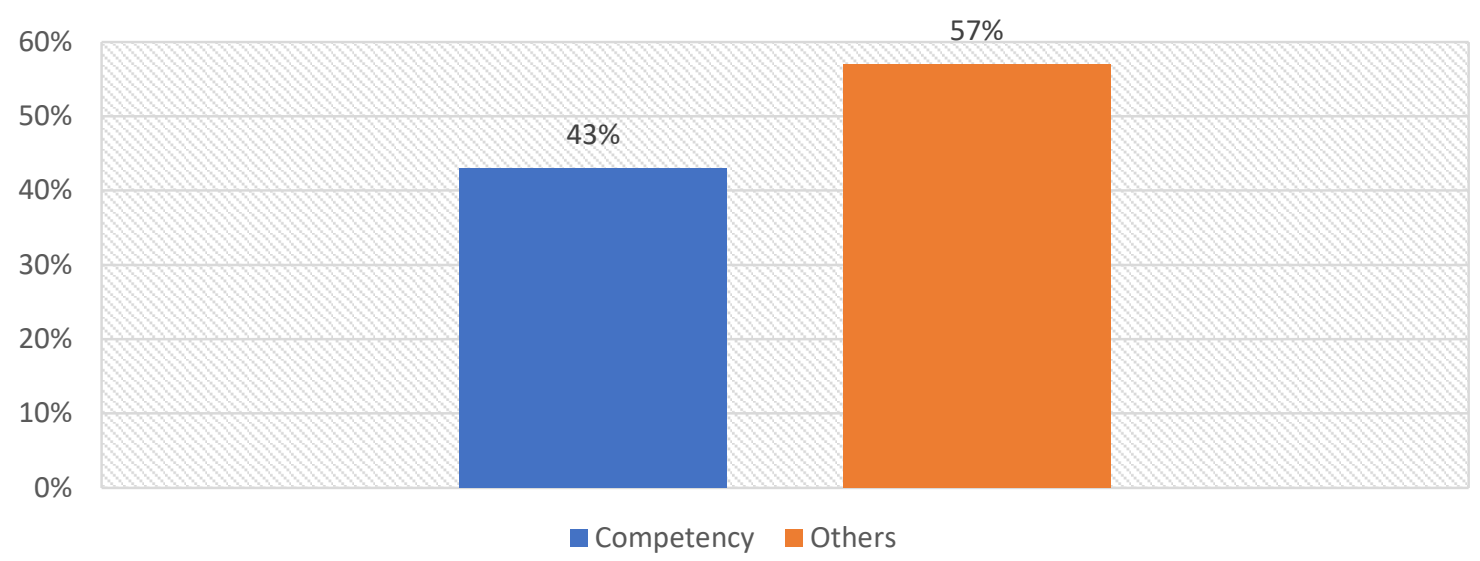

b. Respondents' Reasons to Choose Male or Female as a Political Leader

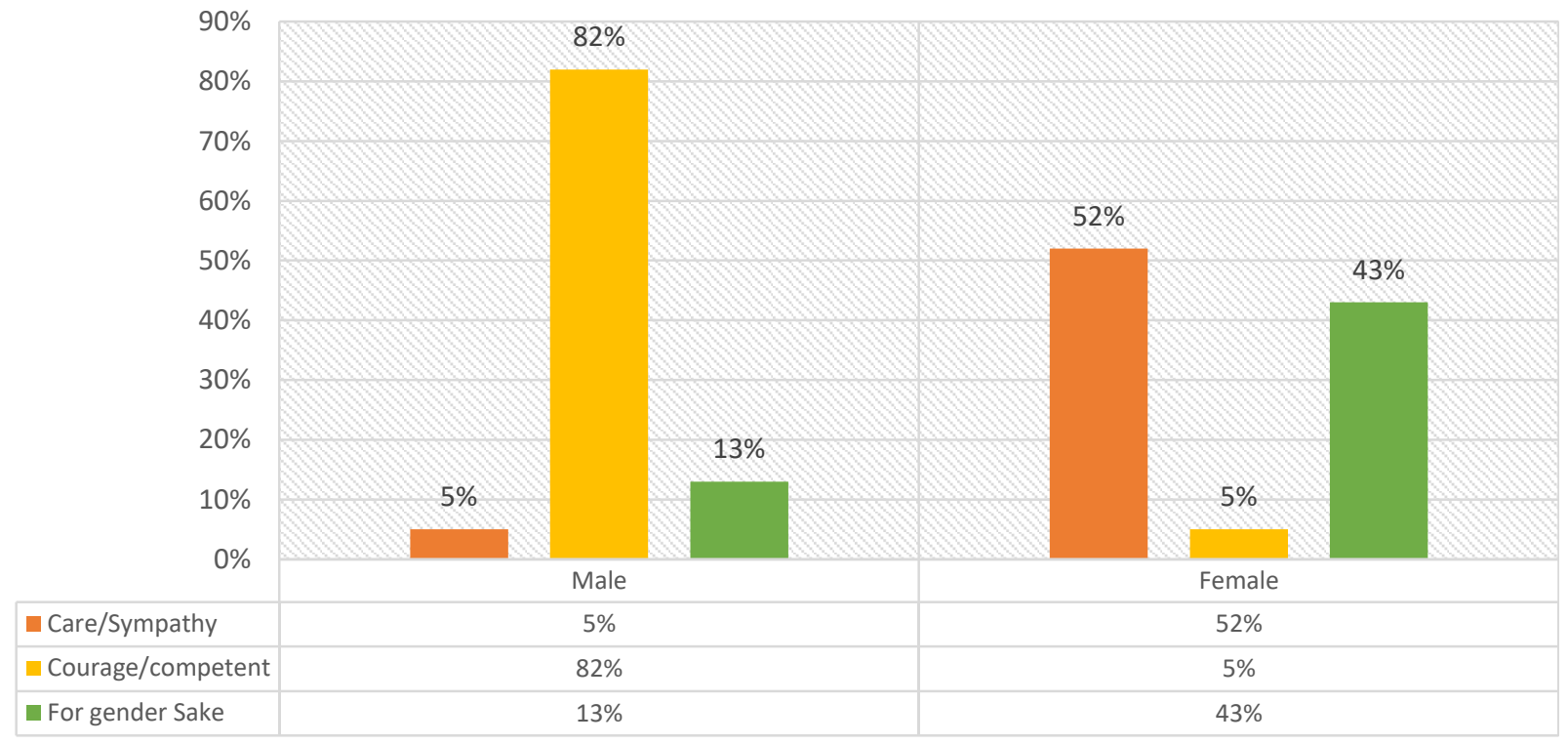

Source: Field survey, 2021

Figure 3 indicates the number of women whose preference for political leaders are based either on competency or other reasons. The figure shows that $43 \%$ of the women respondents said they will look for competency as a basis to select their leaders from both gender. Other reasons apart from competency, as shown in figure 3 (b) amounted to $57 \%$. Figure 3 (b) indicates respondents' choices on leadership - male or female and the reasons for their choices. In all, around $51 \%$ preferred women to be their leaders and $49 \%$ preferred men. Majority of the respondents (52\%) who preferred a female to male leadership said women leaders have care and sympathy for other 
women. A greater number of them (43\%) also said women must lead to affirm equality in leadership. Only $5 \%$ of this category consider competency as a bases to select women as political leaders. The responses suggest that even those who choose women ahead of men, $95 \%$ of them still believe that men are more competent in leadership than the women. On the other hand, majority of respondents (82\%) who prefer male political leadership to that of female said males are very competent and effective in leadership positions than females. During focus group discussions, some men stated that women leaders who supposed to be role models and sources of inspirations to the women in the village rather become pompous and put the women off. This was confirmed by the Ashanti Regional Desk officer of Ministry of Gender, Children and Social Protection when she stated that women leaders rather discourage women than men leaders because these women leaders become proud, disrespectful and self-centered. She cited secondary school headmistresses as women leaders among whom she receives various forms of such complaints. In two of the Districts in the study area (the name of the districts withheld for ethical reasons), the respondents stated during focus group discussion that the female MP and female DCE found in each of the districts were doing nothing to champion the course of women in the area.

Inferiority complex which the concept of othering has been the means to relegate women into the background and perpetuating political inequality seems to have been redefined here. Jensen, (2011) defined othering as "discursive processes by which powerful groups, who may or may not make up a numerical majority, define subordinate groups into existence in a reductionist way which ascribe problematic and/or inferior characteristics to these subordinate groups. Such discursive processes affirm the legitimacy and superiority of the powerful and condition identity formation among the subordinate" (p.65). This definition suggests that marriage and religion have potentials to let women accept that in leadership, men are powerful group and that they fir to lead all the time. Through marital and religious cultures, women themselves accept that men are superior to women - as they oblige to obey Bible and Quran. Thus, religion and marriage do categorise women into subordinates or inferior group. The findings from this current study also show that the description of the behaviour of the few women leaders as pompous, arrogant, and the fact that the respondents cannot affirm the competency of women leaders show that it is not only the others whose discursive processes create the incompetence and the inferiority complex among women but it could be due to other social factors including marriage and religion as social interactions that generate various forms of gender inequalities that affect moral, mental and knowledge development (education) to the disadvantage of woman.

\section{CONCLUSION}

From the findings, it is clear that marriage and religion serve as standing block in women leadership and political decision making in the study area. As religion and marriage put women in a tight position to accept that men are better to lead, the radical feminists who see men as enemies and call for emancipation as means to address the situation are likely to fail in their approach. This is because marriage and religion have power to coin women themselves to accept that men are superior to women hence any attempt to use radical feminism approach as marriage and religion come to play shall fail. 'Gender Othering' is therefore created when ever marriage and religion coerce women to out-group themselves from leadership position. Hence, othering does not only 
Global Journal of Arts, Humanities and Social Sciences

Vol.10, No.1, pp.21-38, 2022

Print ISSN: 2052-6350(Print)

Online ISSN: 2052-6369(Online)

created through just discursive processes but through Socio-cultural processes by which social elements like religion and marriage interactions and gender roles ascribe male and female gender into superior and inferior characteristics respectively, such that both male and female affirm legitimacy and superiority to the male gender rendering radical feminism approach to women emancipation useless. Thus, so far as women continue to involve themselves in marriage and in religion and follow the principles of marriage and religion in Ghana, they shall continue to be subordinates to men.

On the other hand, social and liberal feminists who call for education as means to address the problem are likely to be comfortable in marriage and religion. They are likely to use their rich knowledge to break marriage and religious barriers and ascend into leadership positions. Hence, Rural African Women who enjoy marriage and religion are likely to ascend into any leadership position if they adopt social and liberalist feminism approach in solving the problem. So far as women in the study area (as Africans) enjoy marriage and religion and show maximum respect for husbands and religious leaders, the only means to become leaders and to rule their lives is through education, and earning of higher income.

\section{Recommendation}

What needs to be done to rectify gender othering is to allow education to reform the religious and marriage cultures. With this, an African woman can rule her life.

\section{REFERENCE:}

Oman, C. P. and Arndt, C., (2006). Governance Indicators for Development (No. 33). OECD Publishing.

Oman, C.P. and Arndt, C., (2006). Governance Indicators for Development (No. 33). OECD Publishing.

Beaman, L.; Duflo, E.; Pande, R.; and Topalova, P., (2006). Women Politicians. Gender Bias, and Policy-Making in Rural India. Background Paper, UNICEF.

Berik, G.; Van der Meulen, Rodgers, Y., and Zammit, A., (Eds.). (20120). Social Justice and Gender Equality. Routledge

Brown, S. P. (1996). A meta-analysis and review of organizational research on job involvement. Psychological bulletin, 120(2), p. 235.

Bruegel, I. (1979). Women as a reserve army of labor: a note on recent Britishexperience. Feminist Review, 3(1), 12-23.

Bugingo, I. and Interayamahanga, R., (2010). "A Study on the Development and Use of Governance Indicators in Rwanda", Draft Report.

Capacity.org, (2010). "Editorial Issue 40". Capacity.org. Available at

www.capacity.org/capacity/export/site/Capacity/document/journal . Retrieved on 13 June, 2015.

Chung, B., Kantachote, K., Mallick, A., Polster, R., and Roets, K. (2013). Indicators of women's empowerment in developing nations. In Workshop in International Public Affairs

Collins, P. H. (2000). Gender, black feminism, and black political economy. The Annals of the American Academy of Political and Social Science, 568(1), pp. 41-53.

Corner, L., Repucci, S., and United Nations Development Programme. (2009). A user's guide to measuring Gender-sensitive basic service delivery. UNDP.

@ECRTD-UK: https://www.eajournals.org/

https://doi.org/10.37745/gjahss.2013 
Global Journal of Arts, Humanities and Social Sciences

Vol.10, No.1, pp.21-38, 2022

Print ISSN: 2052-6350(Print)

Online ISSN: 2052-6369(Online)

Chaiken, S., and Trope, Y. (Eds.). (1999). Dual-process theories in social psychology. Guilford Press.

Cuddy, A. J., Fiske, S. T., and Glick, P. (2007). The BIAS map: behaviors from intergroup affect and stereotypes. Journal of personality and social psychology, 92(4), 631.

Ghana. Statistical Service. (2014). Ghana Living Standards Survey Round 6 (GLSS 6): PovertyProfile in Ghana (2005-2013). Ghana Statistical Service.

Inglehart, R., Norris, P., and Ronald, I. (2003). Rising tide: Gender equality and cultural change around the world. Cambridge University Press.

Jensen, S.Q., (2011). Othering, identity formation and agency. Qualitative studies, 2(2), pp.63-78.

Krieger, L.H., (1995). The content of our categories: A cognitive bias approach to discrimination and equal employment opportunity. Stanford Law Review, pp.1161-1248.

Kumar, R. (2018). Research methodology: A step-by-step guide for beginners. Sage.

Liversey, C. and Lawson, T., (2008). AS Sociology foe AQA ( $2^{\text {nd }}$ ed.) Cambridge University Press.

Predelli, L. N. (2004). Interpreting gender in Islam: A case study of immigrant Muslim women in Oslo, Norway. Gender \& society, 18(4), pp. 473-493.

Risman, B. J., (2004). "Gender as a Social Structure: theory wrestling with Activism” Gender and Society. 18(4) pp. 429- 445. Roald

Reskin, B. F., (2000). "The proximate Cause of Employment Discrimination" Contemporary Sociology. Vol.29 No.2 pp. 319-328

Rouhana, H., (2003). On Feminism and National Identity: The experience of Palestinian Women in Israel and Muslim Women in India" Critical Half, Annual Journal of Women for Women International. (1)1 pp. 4-9.

Ryan, W., (1971). Blaming the victim. Vintage.

Sarantakos, S. 2012. Social research. Macmillan International Higher Education.

Scott, C. and Wilde, A., (2006). "Measuring Democratic Governance: A framework for selecting pro-poor and gender sensitive indicators", United Nations Develop Programme, Oslo.

Seidman, S. (2013). "Defilement and Disgust: Theorising the Other" American Journal of Cultural Sociology, 1, pp. 3-25.

Smelser, N. J. (1988). Handbook of sociology. Sage Publications.

Swadener, B. B., and Lubeck, S. (Eds.). (1995). Children and families" at promise":Deconstructing the discourse of risk. SUNY Press.

Tilly, C., (1998). Durable Inequality. University of California Press, Berkeley, CA

Twumasi, P. (2001). Social research in rural communities. Ghana University Pre

UN, (2014). Women's Right are Human Right. UN Publication No. E.14XIV.5

UN Women, (2014). Strategic Guide Political Empowerment of Women: Framework for, Strategic Action in Latin America and the Caribbean (2014 - 2017)

Valencia, R.R. and Solórzano, D.G., (1997) Contemporary deficit thinking. The evolution of deficit thinking: Educational thought and practice

Wadud, A. (1999). Quran and Woman: Rereading the Sacred Text from a Woman's.Perspective. Oxford University Press.

Whelehan, I., and Pilcher, J., (2004). Fifty key concepts in gender studies. Sage.

@ECRTD-UK: https://www.eajournals.org/

https://doi.org/10.37745/gjahss.2013 
Global Journal of Arts, Humanities and Social Sciences

Vol.10, No.1, pp.21-38, 2022

Print ISSN: 2052-6350(Print)

Online ISSN: 2052-6369(Online)

Willis, J. D., (2007). Foundation of Quantitative Research: Interpretative and Critical Approaches. Thousand oaks, CA. sage

Walby, S. (1990). Theorizing Patriarchy, Oxford: Blackwell.

@ECRTD-UK: https://www.eajournals.org/

https://doi.org/10.37745/gjahss.2013 